\title{
Pengaruh Tingkat Pendidikan dan Budaya Hukum Terhadap Kepatuhan Hukum Warga Jambi Dalam Menerapkan Protokol kesehatan Covid-19
}

\author{
Yuslistia Opeska $^{1}$, Irzal Anderson ${ }^{2}$, Kuswanto $^{3}$ \\ ${ }^{123}$ Pendidikan PKn FKIP UNJA \\ Email: ${ }^{1}$ yuslistiaopeska@gmail.com; ${ }^{2}$ irzalandrson@gmail.com; \\ ${ }^{3}$ kuswantomsi14@gmail.com
}

\begin{abstract}
Abstrack
This study aims to determine the effect of the level of education and legal culture on the legal compliance of Jambi City residents in implementing the Covid-19 health protocol. This research is a quantitative research with multiple regression analysis conducted in Jambi City in general. The data collection technique used is a questionnaire (questionnaire) that is distributed directly to respondents. Based on data analysis that has been carried out using multiple regression models with the help of SPSS version 25, it is proven that the education level variable (XI) and the legal culture variable (X2) simultaneously have a significant effect on the legal compliance variable $(Y)$. This can be seen from the basis of decision making from the p-value $<$ sig alpha $(\alpha=5 \%)$, namely $0.000<0.05$, which means that the independent variable has a significant influence on the dependent variable. The effect of the independent variable on the dependent variable amounted to 0.147 or 14.7\%. This means that the education level variable (X1) and legal culture (X2) jointly affect legal compliance (Y) by $14.7 \%$ while the remaining $85.3 \%$ (100\% $14.7 \%)$ influenced by other variables not examined.
\end{abstract}

Keywords: legal culture, legal compliance Education level

\begin{abstract}
Abstrak
Penelitian ini bertujuan untuk mengetahui pengaruh dari tingkat pendidikan dan budaya hukum terhadap kepatuhan hukum warga Kota Jambi dalam menerapkan protokol kesehatan covid-19. Penelitian ini merupakan penelitian kuatitatif dengan analisis regresi berganda yang dilakukan di Kota Jambi secara umum. Teknik pengumpulan data yang digunakan ialah kuesioner (angket) yang disebarkan secara langsung kepada responden. Berdasarkan analisis data yang elah dilakukan menggunakan model regresi ganda dengan bantuan SPSS versi 25, terbukti bahwa variabel tingkat pendidikan $\left(\mathrm{X}_{1}\right)$ dan variabel budaya hukum $\left(\mathrm{X}_{2}\right)$ secara simultan berpengaruh signifikan terhadap variabel kepatuhan hukum $(\mathrm{Y})$. Hal tersebut dapat dilihat dari dasar pengambilan keputusan dari nilai p-value $<$ sig alpha $(\alpha=5 \%)$ yaitu $0,000<0,05$ yang berarti variabel independen memberikan pengaruh secara signifikan terhadap variabel dependen. Pengaruh yang ditimbulkan dari variabel independen terhadap variabel dependen ialah sebesar sebesar 0,147 atau $14,7 \%$. Artinya variabel tingkat pendidikan $\left(\mathrm{X}_{1}\right)$ dan budaya hukum $\left(\mathrm{X}_{2}\right)$ secara bersamasama berpengaruh terhadap kepatuhan hukum $(\mathrm{Y})$ sebesar $14,7 \%$ sementara sisanya sebesar $85,3 \%(100 \%-14,7 \%)$ dipengaruhi oleh variabel lain yang tidak diteliti.
\end{abstract}

Kata kunci: budaya hukum, kepatuhan hukum, budaya hukum, kepatuhan hukum. 


\section{Pendahuluan}

Pada saat ini dunia sedang dikagetkan dengan wabah penyakit menular yaitu virus corona (COVID-19) tidak terkecuali juga dengan negara tercinta Indonesia, penyebaran virus yang berawal dari kota Wuhan China ini menimbulkan berbagai dampak diberbagai sektor kehidupan masyarakat. Pandemi virus yang mewabah ini menimbulkan ketakutan dan kekhawatiran bagi masyarakat dan pemerintah, pasalnya segala aktivitas menjadi terhambat karena virus tersebut, penyebarannya yang begitu pesat membuat pemerintah harus mengambil keputusan untuk mengatasi permasalahan yang sedang terjadi. Kemudian pemerintah memberlakukan Pembatasan Sosial Berskala Besar (PSBB) dan New Normal untuk mengatasi permasalahan yang disebabkan oleh Covid-19 diberbagai sektor kehidupan.

New normal merupakan istilah yang dipakai pemerintah untuk menciptakan suatu tatanan kehidupan normal baru, yang artinya masyarakat harus membiasakan kehidupan sebagaimana mestinya dengan hidup berdampingan dengan virus tersebut dengan berbagai aturan yang harus dipatuhi agar pandemi virus corona tidak mengalami lonjakan dikarenakan new normal. Salah satunya adalah dengan menerapkan protokol kesehatan Covid-19 yaitu 3M (Menjaga jarak, Menggunakan masker, dan selalu Mencuci tangan menggunakan air yang mengalir). Kebiasaan $3 \mathrm{M}$ yang baru bagi masyarakat membuat protokol ini berjalan dengan berbagai hambatan salah satunya ialah kebiasaan masyarakat yang tidak terbiasa dengan aturan yang dibuat. Pemerintah menerapkan denda dan sanksi bagi pelanggar protokol Covid-19 berupa denda uang senilai Rp.50.000 dan sanksi berupa memungut sampah dan lain sebagainya. Hukuman tersebut diterapkan agar masyarakat mematuhi aturan protokol yang telah diterapkan. Namun pada kenyataannya masih saja ada masyarakat yang tidak mau mematuhi aturan tersebut, masih sering dijumpai masyarakat yang berkeliaran di jalanan umum tanpa mengenakan masker, dan masih banyak sekali masyarakat yang masih berkerumun di tempat umum terutama di tempat perbelanjaan. Hal ini sudah jelas melanggar aturan protokol covid-19, tanpa disadari hal ini bisa membahayakan orang yang melanggarnya dan orang lain. Banyaknya kasus corona dengan status orang tanpa gejala menyebabkan sulitnya mengidentifikasi siapa-siapa saja yang terpapar virus tersebut, sehingga masker sangat penting untuk meminimalisir hal yang tidak diinginkan tersebut, namun sebagian masyarakat dengan egoisnya tanpa memikirkan akibat yang akan timbul di masa yang akan datang bertindak dengan sesuka hatinya. Hal tersebut dibuktikan dengan pertanggal 18 Desember 2020 denda dari pelanggaran protokol kesehatan mencapai Rp.199.700.000 juta didapatkan dari pelanggaran pelaku usaha sebanyak Rp.76.000.000 juta dengan jumlah pelanggar 17 tempat usaha, kemudian denda dari tidak memakai masker mencapai Rp.123.700.000 juta dengan jumlah pelanggar 2.474 orang. Kemudian untuk tempat usaha terdapat 601 yang diberikan peringatan, 17 usaha diberi denda, serta 22 usaha disegel. Tempat usaha tersebut meliputi cafe, toserba, tempat fitness, hotel dan tempat publik lainnya. (Sumber: jambione.com)

Pelanggaran atas protokol tersebut sangat berdampak terhadap bertambahnya kasus positif Covid-19 di Indonesia terkhusus di Provinsi Jambi 
tercinta. Kepatuhan hukum masyarakat dalam mematuhi protokol covid-19 di Provinsi Jambi terbilang cukup rendah, hal ini dapat dilihat dari penambahan kasus positif setiap harinya. Berdasarkan data dari satuan tugas penanganan Covid-19 Nasional didapatkan data bahwa Provinsi Jambi mengalami kenaikan kasus positif sebesar 35,4\% dengan penyumbang tertinggi dari Kota Jambi sebesar $32,82 \%$ dengan data sebagai berikut:

Tabel 4.1 Data Peningkatan Kasus Positif Covid-19 di Provinsi Jambi

\begin{tabular}{|c|c|c|c|c|}
\hline $\begin{array}{c}\text { Jumlah Kasus } \\
\text { Tertinggi }\end{array}$ & $\begin{array}{c}\text { Insiden } \\
\text { Komulatif } \\
\text { Tertinggi }\end{array}$ & $\begin{array}{c}\text { Kenaikan } \\
\text { Kasus Tertinggi }\end{array}$ & $\begin{array}{c}\text { Jumlah } \\
\text { Kematian } \\
\text { Komulatif } \\
\text { Terbanyak }\end{array}$ & $\begin{array}{c}\text { Tingkat } \\
\text { Kesembuhan } \\
\text { Terendah }\end{array}$ \\
\hline $\begin{array}{l}\text { Kota Jambi: } \\
\text { 1,182 kasus }\end{array}$ & $\begin{array}{c}\text { Kota Jambi: } \\
191.77 \text { kasus per } \\
10,000 \text { penduduk }\end{array}$ & $\begin{array}{l}\text { Kota Jambi: naik } \\
54.2 \% \text { (59 vs } 91)\end{array}$ & Kota Jambi: 12 & $\begin{array}{c}\text { Kota Jambi: } \\
65.23 \%\end{array}$ \\
\hline $\begin{array}{c}\text { Kab. Muaro } \\
\text { Jambi: } 383 \text { kasus }\end{array}$ & $\begin{array}{c}\text { Kab. Muaro } \\
\text { Jambi: } 190.95 \\
\text { kasus per } \\
100,000 \\
\text { penduduk }\end{array}$ & $\begin{array}{c}\text { Kab. Bungo: } \\
\text { naik > } 2 \times \text { lipat } \\
(13 \text { vs } 42)\end{array}$ & Kab. Tebo: 10 & $\begin{array}{c}\text { Kab. Bungo: } \\
66.16 \%\end{array}$ \\
\hline $\begin{array}{c}\text { Kab. Batanghari: } \\
329 \text { kasus }\end{array}$ & $\begin{array}{c}\text { Kota Sungai } \\
\text { Penuh: } 104.06 \\
\text { kasus per } \\
100,000 \\
\text { penduduk }\end{array}$ & $\begin{array}{c}\text { Kab. Muaro } \\
\text { Jambi: naik >2× } \\
\text { lipat }(10 \text { vs } 29)\end{array}$ & Kab. Kerinci: 8 & $\begin{array}{c}\text { Kab. Kerinci: } \\
66.89 \%\end{array}$ \\
\hline - & - & - & $\begin{array}{l}\text { Kab. Batanghari: } \\
8\end{array}$ & $\begin{array}{c}\text { Kab. Tanjung } \\
\text { Jabung Barat: } \\
69.6 \%\end{array}$ \\
\hline- & - & - & Kab. Bungo: 6 & $\begin{array}{c}\text { Kab. Tebo: } \\
70.83 \%\end{array}$ \\
\hline
\end{tabular}

Sumber: satuan penanganan Covid Nasional per tanggal 10 Januari 2021 diolah

Data diatas tersebut dapat dilihat bahwa Kota Jambi menjadi penyumbang terbesar peningkatan kasus positif di Provinsi Jambi, bahkan Kota Jambi merupakan kota dengan kasus tertinggi, insiden komulatif tertinggi, jumlah kematian terbanyak, serta tingkat kesembuhan paling rendah seprovinsi Jambi. Hal ini menimbulkan pertanyaan mengapa Kota Jambi menjadi Kota yang dapat dikatakan yang terparah dalam kasus pandemi Covid-19 dibandingkan dengan 10 Kabupaten/Kota lainnya. Kemudian peningkatan kasus tersebut sejalan dengan rendahnya kepatuhan masyarakat Provinsi Jambi dalam mematuhi protokol Covid-19. Hal ini dibuktikan dari hasil monitoring protokol covid-19 yang dilakukan oleh Satuan Penanganan Covid Nasional per tanggal 10 Januari 2021 bahwa Provinsi Jambi menempati peringkat ke-31 dari 34 Provinsi yang ada di Indonesia berdasarkan persentase kepatuhan memakai masker, kemudian Provinsi Jambi juga menempati peringkat ke-26 dari 34 Provinsi yang ada di Indonesia berdasarkan persentase kepatuhan menjaga jarak dan menghindari kerumunan. Dapat disimpulkan dari data tersebut bahwa kepatuhan masyarakat Provinsi Jambi dalam mematuhi protokol kesehatan masih rendah dibandingkan dengan provinsi lain. (Sumber: Satgas Penanganan Covid-19 Nasional diolah) 
Permasalahan kepatuhan masyarakat tersebut sangat menarik untuk ditelusuri akar penyebabnya yang membuat kepatuhan masyarakat dalam mematuhi protokol kesehatan menjadi rendah. Hal tersebut dapat disebabkan oleh tingkat pendidikan masyarakat, tingkat pendidikan yang beragam menyebabkan edukasi terhadap pentingnya mematuhi protokol kesehatan juga beragam, masyarakat yang memiliki pendidikan yang lebih tinggi akan memiliki pengetahuan yang lebih, sehingga lebih mengetahui mengenai peraturan yang diberlakukan dan memiliki kesadaran hukum yang tinggi untuk mematuhi peraturan yang ada. Kepatuhan hukum dapat diartikan sikap setia dan taatnya masyarakat terhadap suatu nilai hukum yang telah ada bukan disebabkan adanya sanksi yang berlaku ataupun adanya penegak hukum yang mengawasi, namun sikap yang timbul dari kesadaran masing-masing masyarakat atas suatu hukum yang sedang berlaku.

Menurut Soekanto (1982:230) bahwa kepatuhan dari seorang merupakan akibat dari proses dari pengaruh-pengaruh sosial yang yang memberikan akibat pada pemahaman seseorang, sikap maupun pola perikelakuan dan hal tersebut berasal dari orang yang berada dalam kelompok tersebut. Berdasarkan teori yang telah dijelaskan bahwa kepatuhan hukum dapat timbul karena adanya paksaan agar seseorang mematuhi hukum yang berlaku tersebut, kemudian dapat juga timbul karena penerimaan masyarakat terhadap nilai-nilai hukum tersebut.

Menurut H.C. Kelman (Pujirahayu, 2020:126) derajat kepatuhan hukum secara kualitatif dapat dibedakan menjadi 3 (tiga) proses yaitu sebagai berikut:

a) Compliance

Diartikan sebagai suatu kepatuhan yang didasari karena mengharapkan suatu imbalan atau menghindari hukuman yang akan diberikan. Artinya seseorang akan mematuhi hukum apabila ada imbalan dan ada hukuman yang ditetapkan. Maka suatu kepatuhan akan tercipta jika diawasi dengan ketat oleh pemegang wewenang atas penerapan kaidah hukum tersebut.

b) Identification

Hal ini terjadi jika kepatuhan terhadap nilai hukum bukan karena nilai intrinsik yang terkandung didalamnya tetapi karena agar setiap anggota kelompok tersebut tetap terjalin serta ada hubungan baik dengan orang yang diberikan wewenang untuk melaksanakan kaidah hukum tersebut. kepatuhan terhadap hukum didasarkan pada keuntungan yang akan didapatkan jika berhubungan baik dengan pemegang wewenang tersebut. jadi kepatuhan terhadap kaidah tersebut tergantung seberapa baiknya hubungan yang dimiliki seseorang tersebut.

c) Internalization

Hal ini terjadi jika seseorang mematuhi kaidah hukum karena secara instrinsik kepatuhan tersebut memiliki imbalan. Isi dari kaidah hukum tersebut sesuai dengan nilai-nilainya sejak pengaruh terjadi. Pusat dari proses ini adalah adanya kepercayaan seseorang terhadap tujuan dari kaidah tersebut, dengan mengesampingkan penilaiannya terhadap pemegang kekuasaan dan pengawasan kaidah tersebut.

Data tingkat pendidikan penduduk berumur 15 tahun keatas di Kota Jambi dapat dilihat pada diagram sebagai berikut: 


\section{Diagram 7.1 Persentase Pendidikan Penduduk Berumur 15 Tahun Keatas}

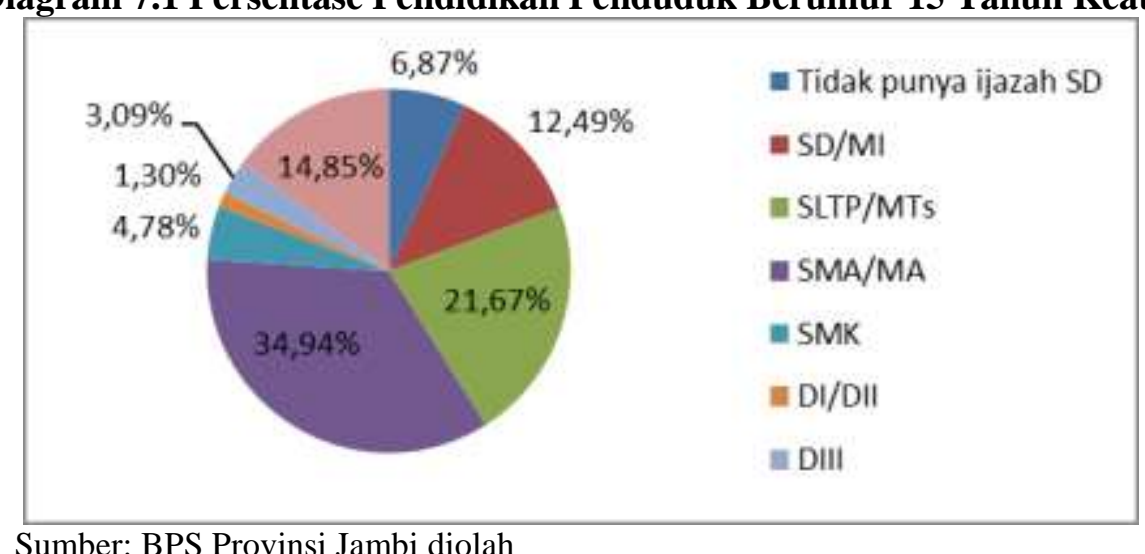

Dari diagram diatas bisa dilihat jika tingkat pendidikan penduduk Kota Jambi masih tergolong rendah, persentase masyarakat yang memiliki pendidikan tinggi lebih kecil dibandingkan masyarakat yang memiliki pendidikan menengah kebawah. Sehingga kepatuhan masyarakat dalam menerapkan protokol kesehatan dapat dipengaruhi dengan jenjang pendidikan masyarakat yang rendah. Hal ini sejalan dengan pendapat (Kakunsi, dkk (2017) yang menyatakan bahwa tingkat pendidikan dapat memberikan pengaruh atas perubahan dari sikap dan juga perilaku hidup sehat individu tersebut. Seseorang yang memiliki tingkat pendidikan yang lebih tinggi akan mempermudah orang tersebut atau masyarakat untuk mengolah informasi yang diterimanya dan menerapkannya dalam perilaku hidup sehari-hari, terkhusus dalam hal kesehatan. Karena pendidikan formal membentuk nilai bagi seseorang dalam menerima hal baru.

Hal tersebut juga sejalan dengan penelitian yang dilakukan oleh Erica Kakunsi, Sifrid Pangemanan, dan Winston Pontoh (2017) "Pengaruh Gender dan Tingkat Pendidikan Terhadap Kepatuhan Wajib Pajak di Wilayah Kantor Pelayanan Pajak Pratama Tahuna". Berdasarkan pembahasan dan hasil penelitian dapat disimpulkan bahwa tingkat pendidikan memberikan pengaruh langsung terhadap kepatuhan pajak orang pribadi, hal ini dibuktikan dengan hasil uji ANOVA diperoleh hasil nilai sig $0,000<0,05$ sehingga $\mathrm{H}_{0}$ ditolak dan menerima $\mathrm{H}_{\mathrm{a}}$. Sedangkan penelitian yang dilakukan oleh Kadek Ayu Agustina (2016) yang berjudul "Pengaruh Tingkat Pendidikan, Tingkat Penghasilan, dan Tarif Pajak Terhadap Kepatuhan Wajib Pajak UMKM dalam Memenuhi Kewajiban Perpajakan (studi empiris pelaku UMKM di Kabupaten Buleleng)". Berdasarkan pembahasan dan hasil penelitian dapat ditarik kesimpulan bahwa tingkat pendidikan secara parsial memiliki pengaruh terhadap kepatuhan wajib pajak UMKM dibuktikan berdasarkan hasil analisis diperoleh nilai sig. sebesar 0,046 > 0,05 sehingga $\mathrm{H}_{1}$ diterima. Tingkat pendidikan memiliti pengaruh yang positif terhadap kepatuhan wajib pajak UMKM. Dari kedua hasil penelitian terdahulu tersebut semakin memperkuat teori dan hipotesis yang diajukan dalam penelitian ini mengenai pengaruh dari tingkat pendidikan terhadap kepatuhan hukum.

Kepatuhan masyarakat terhadap protokol kesehatan dapat juga dipengaruhi oleh faktor budaya hukum, budaya hukum masyarakat yang rendah 
akan sangat mempengaruhi kepatuhan hukum dari masyarakat tersebut. Budaya hukum berkaitan erat dengan penegakan hukum yang menyangkut keyakinan masyarakat kepada hukum dan para penegak hukum. Jika budaya hukum yang baik sudah tercipta maka akan hadir sebuah kepatuhan hukum dalam masyarakat. Budaya hukum terbentuk sebagai hasil dari sebuah kesadaran hukum masyarakat. Hal tersebut sesuai dengan yang disampaikan oleh Lawrence M. Friedman (Prakoso, 2017:199) seseorang menggunakan hukum atau tidak, serta patuh hukum atau tidak sangat bergantung dari kultur hukumnya. Hal tersebut berarti kultur atau budaya hukum dari seseorang itulah yang akan menentukan kepatuhan hukum dari seseorang tersebut, seperti apa budaya hukum yang dianutnya dikesehariannya menjadi penentu kepatuhan hukumnya.

Hukum sangat bergantung pada jiwa dari masyarakat yang menjadi isi dari hukum tersebut ditentukan dari pergaulan hidup individu dari waktu ke waktu. Hal tersebut menunjukkan seberaba pentingnya hukum jika dikaitkan dengan struktur masyarakat pendukung dari hukum tersebut dan sistem nilai-nilai budaya yang ada didalam masyarakat. Hal ini sesuai dan sejalan dengan hasil penelitian yang dilakukan oleh Ika Darmika (2016) yang berjudul Budaya Hukum (Legal Culture) dan Pengaruhnya Terhadap Penegakan Hukum di Indonesia". Berdasarkan pembahasan dapat disimpulkan bahwa perbedaan persepsi masyarakat terhadap ketentuan perundang-undangan akan menimbulkan akibat bahwa penegakan hukumnya juga berbeda antara kelompok masyarakat tertentu dan kelompok masyarakat lain. Dan budaya termasuk ke dalam salah satu faktor yang mempengaruhi penegakan hukum.

Menurut Muladi budaya hukum merupakan salah satu bagian penting dalam penegakan hukum selain dari struktur dan substansi hukum. Budaya hukum diartikan perilaku seseorang terhadap hukum ataupun sistem hukum, sebagai iklim dari pemikiran sosial dan kekuatan sosial yang menjadi penentu cara hukum tersebut digunakan, dihindari ataupun disalahgunakan dalam masyarakat (Prakoso, 2017:196). Berdasarkan penjelasan dan data yang telah peneliti uraikan, peneliti tertarik untuk melakukan penelitian untuk mengetahui apakah Tingkat Pendidikan dan Budaya masyarakat dapat mempengaruhi Kepatuhan Hukum masyarakat dalam mematuhi protokol kesehatan covid-19 di Kota Jambi yang peneliti tuangkan dalam judul "Pengaruh Tingkat Pendidikan dan Budaya Hukum Terhadap Kepatuhan Hukum Warga Kota Jambi dalam Menerapkan Protokol Kesehatan Covid-19”. Tujuan dilaksanakan penelitian ini ialah untuk mengetahui pengaruh Tingkat Pendidikan dan Budaya Hukum terhadap Kepatuhan Hukum warga Kota Jambi dalam menerapkan protokol kesehatan covid-19.

\section{Metode Penelitian}

Metode penelitian yang digunakan dalam penelitian ini adalah kuantitatif dengan analisis regresi. Data yang diperoleh dari sampel populasi diolah dengan menggunakan metode statistik yaitu analisis regresi dengan terlebih dahulu dilakukan uji prasayarat analisis yang meliputi uji normalitas, uji linieritas, uji multikolinieritas, dan uji heteroskedastisitas kemudian hasil yang diperoleh dijadikan regenelisasi. Penelitian dengan analisis regresi dalam penelitian ini bertujuan untuk mngetahui pengaruh dari tingkat pendidikan dan budaya hukum 
masyarakat Kota Jambi terhadap kepatuhan hukum warga Kota Jambi dalam menerapkan protokol kesehatan covid-19. Pengumpulan data dilakukan dengan penyebaran angket secara langsung kepada responden dengan jenis angket tertutup. Tempat dilaksanakan penelitian ini adalah di Kota Jambi yang terdiri dari 11 Kecamatan dan 62 Kelurahan dan mulai dilaksanakan pada tanggal 23 Maret 2021 - 1 April 2021. Populasi dalam penelitian ini meliputi masyarakat Kota Jambi secara umum, sampel penelitian ini ditentukan dengan cara area sampling secara purposive, sehingga diperoleh jumlah sampel sebanyak 278 responden. Teknik analisis dalam penelitian ini menggunakan statistik dengan teknik analisis regresi berganda.

\section{Hasil dan Pembahasan}

\section{Deskripsi Tingkat Pendidikan}

Berikut ini disajikan tabel yang menjelaskan mengenai deskripsi tingkat pendidikan warga Kota Jambi:

Tabel 11.1 Deskripsi Tingkat Pendidikan

\begin{tabular}{|c|l|c|c|c|c|}
\hline NO & JENJANG & KELAS & FREKUENSI & PERSENTASE & KATEGORI \\
\hline 1 & PT & 4 & 86 & $30.9 \%$ & Sangat Tinggi \\
\hline 2 & SMA & 3 & 153 & $55.0 \%$ & Tinggi \\
\hline 3 & SMP & 2 & 26 & $9.4 \%$ & Rendah \\
\hline 4 & SD TOTAL & 1 & 13 & $4.7 \%$ & Sangat Rendah \\
\hline \multicolumn{2}{|c|}{} & 278 & $100 \%$ & \\
\hline
\end{tabular}

Berdasarkan tabel diatas dapat diketahui bahwa nilai frekuensi jawaban masyarakat terhadap kuesioner (angket) tingkat pendidikan formal yang dikelompokkan dalam empat kategori yaitu: sangat tinggi sebanyak 86 responden (30.9\%), tinggi sebanyak 153 responden $(55.0 \%)$, rendah sebanyak 26 responden $(9.4 \%)$, dan sangat rendah sebanyak 13 responden (4.7\%). Berdasarkan tabel diatas dapat diketahui bahwa sebagian besar tingkat pendidikan masyarakat Kota Jambi adalah SMA yaitu sebesar 55\%.

\section{Deskripsi Budaya Hukum}

Untuk mengetahui dan memperjelas mengenai budaya hukum warga Kota Jambi dapat dilihat pada tabel sebagai berikut:

Tabel 11.2 Deskripsi Budaya Hukum

\begin{tabular}{|c|c|c|c|c|}
\hline NO & KELAS & FREKUENSI & PERSENTASE & KATEGORI \\
\hline 1 & $26-32$ & 56 & $20 \%$ & Sangat Tinggi \\
\hline 2 & $20-25$ & 123 & $44 \%$ & Tinggi \\
\hline 3 & $14-19$ & 67 & $24 \%$ & Rendah \\
\hline 4 & $8-13$ & 32 & $12 \%$ & Sangat Rendah \\
\hline \multicolumn{2}{r|}{ TOTAL } & 278 & $100 \%$ & \\
\hline
\end{tabular}

Berdasarkan tabel diatas dapat diketahui bahwa nilai frekuensi jawaban masyarakat terhadap kuesioner (angket) variabel budaya hukum yang 
dikelompokkan dalam empat kategori yaitu: sangat tinggi sebanyak 56 responden (20\%), tinggi sebanyak 123 responden (44\%), rendah sebanyak 67 responden (24\%), dan sangat rendah sebanyak 32 responden (12\%). Berdasarkan tabel diatas dapat diketahui bahwa sebagian besar masyarakat Kota Jambi memiliki budaya hukum yang baik sebesar $44 \%$ dengan kategori tinggi, yang terletak pada interval 20-25. Kemudian untuk mengetahui hasil dari masing-masing indikator budaya hukum dapat dilihat pada tabel sebagai berikut:

Tabel 12.1 Skor Indikator Budaya Hukum

\begin{tabular}{|c|c|c|c|c|}
\hline NO & INDIKATOR & इSKOR & \%SKOR & KATEGORI \\
\hline 1 & Parokial & 713 & $12.21 \%$ & Sangat Rendah \\
\hline 2 & Subjek & 1.295 & $22.18 \%$ & Rendah \\
\hline 3 & Partisipan & 3.831 & $65.61 \%$ & Baik \\
\hline \multicolumn{2}{|c|}{ KESELURUHAN } & 5.839 & $65.64 \%$ & Baik \\
\hline
\end{tabular}

Dari tabel diatas dapat diketahui bahwa untuk indikator Parokial masyarakat Kota Jambi sejumlah 713 atau $12.21 \%$ yang berarti bahwa budaya hukum tipe parokial masyarakat termasuk dalam kategori sangat rendah. Kemudian pada indikator Subjek memiliki skor 1.295 atau $22.18 \%$ yang berarti bahwa budaya hukum tipe subjek masyarakat termasuk dalam kategori rendah. Sedangkan pada indikator Partisipan memiliki skor 3.831 atau $65.61 \%$ yang berarti bahwa budaya hukum tipe partisipan masyarakat termasuk dalam kategori baik. Sehingga secara keseluruhan untuk variabel budaya hukum memiliki skor 5.839 atau $65.64 \%$ yang artinya bahwa budaya hukum masyarakat Kota Jambi berada pada kategori baik.

\section{Deskripsi Kepatuhan Hukum}

Untuk lebih memperjelas hasil penelitian berkenaan dengan kepatuhan hukum menerapkan protokol kesehatan covid-19 warga Kota Jambi maka disajikan tabel sebagai berikut:

Tabel 12.2 Deskripsi Kepatuhan Hukum

\begin{tabular}{|c|c|c|c|c|}
\hline NO & KELAS & FREKUENSI & PERSENTASE & KATEGORI \\
\hline 1 & $25-30$ & 47 & $17 \%$ & sangat tinggi \\
\hline 2 & $19-24$ & 126 & $45 \%$ & Tinggi \\
\hline 3 & $13-18$ & 75 & $27 \%$ & Rendah \\
\hline 4 & $7-12$ & 30 & $11 \%$ & sangat rendah \\
\hline \multicolumn{2}{|c|}{ TOTAL } & 278 & $100 \%$ & \\
\hline
\end{tabular}

Berdasarkan tabel diatas dapat diketahui bahwa nilai frekuensi jawaban masyarakat terhadap kuesioner (angket) variabel kepatuhan hukum yang dikelompokkan dalam empat kategori yaitu: sangat tinggi sebanyak 47 responden (17\%), tinggi sebanyak 126 responden (45\%), rendah sebanyak 75 responden $(27 \%)$, dan sangat rendah sebanyak 30 responden (11\%). Berdasarkan tabel diatas dapat diketahui bahwa sebagian besar masyarakat Kota Jambi memiliki kepatuhan hukum yang baik sebesar $45 \%$ dengan kategori tinggi, yang terletak pada interval 
19-24. Kemudian untuk mengetahui hasil dari masing-masing indikator kepatuhan hukum dapat dilihat pada tabel sebagai berikut:

Tabel 13.1 Skor Indikator Kepatuhan Hukum

\begin{tabular}{|c|l|c|c|c|}
\hline NO & INDIKATOR & $\boldsymbol{\Sigma}$ SKOR & \%SKOR & KATEGORI \\
\hline 1 & Compliance & 2.310 & $42.62 \%$ & Cukup \\
\hline 2 & Identification & 2.321 & $42.82 \%$ & Cukup \\
\hline 3 & Internalization & 789 & $14.56 \%$ & Sangat Rendah \\
\hline \multicolumn{2}{|c|}{ KESELURUHAN } & 5.420 & $69.63 \%$ & Baik \\
\hline
\end{tabular}

Dari tabel diatas dapat diketahui bahwa untuk indikator Compliance masyarakat Kota Jambi sejumlah 2.310 atau $42.62 \%$ yang berarti bahwa kepatuhan hukum tipe compliance masyarakat termasuk dalam kategori cukup. Kemudian pada indikator Identification memiliki skor 2.321 atau $42.82 \%$ yang berarti bahwa kepatuhan hukum tipe identification masyarakat termasuk dalam kategori cukup. Sedangkan pada indikator Internalization memiliki skor 789 atau $14.56 \%$ yang berarti bahwa kepatuhan hukum tipe internalization masyarakat termasuk dalam kategori sangat rendah. Sehingga secara keseluruhan untuk variabel kepatuhan hukum memiliki skor 5.420 atau $69.63 \%$ yang artinya bahwa kepatuhan hukum masyarakat Kota Jambi berada pada kategori baik.

\section{Uji Hipotesis Secara Simultan}

Uji simultan dilakukan untuk mengetahui pengaruh yang diberikan variabel X (Tingkat Pendidikan dan Budaya Hukum) secara bersama-sama terhadap variabel Y (Kepatuhan Hukum). Dalam penelitian ini hasil dari uji simultan disajikan dalam tabel sebagai berikut:

Tabel 14.1 Uji Simultan

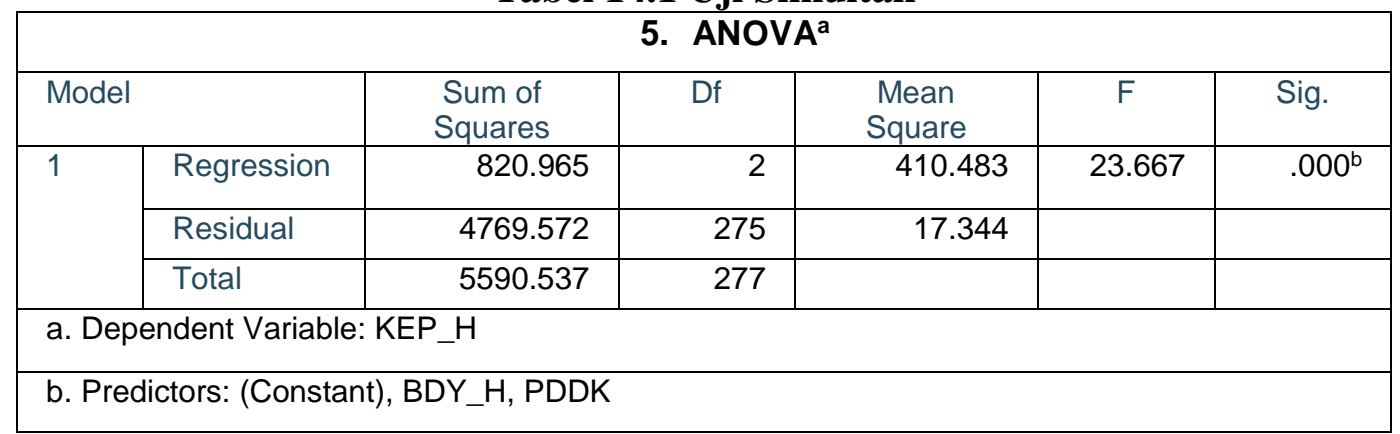

Berdasarkan tabel tersebut diketahui nilai sig sebesar $0,000<0,05$. Berdasarkan dasar pengambilan keputusan uji simultan dapat disimpulkan bahwa $\mathrm{H}_{0}$ ditolak dan menerima $\mathrm{H}_{\mathrm{a}}$ yang artinya terdapat pengaruh antara variabel tingkat pendidikan $\left(\mathrm{X}_{1}\right)$ dan budaya hukum $\left(\mathrm{X}_{2}\right)$ secara bersama-sama terhadap variabel kepatuhan hukum (Y).

\section{Uji Hipotesis Secara Parsial}

Uji parsial dilakukan untuk mengetahui pengaruh masing-masing variabel $\mathrm{X}$ yaitu Tingkat Pendidikan dan Budaya Hukum secara sendiri-sendiri terhadap 
variabel Y yaitu Kepatuhan Hukum. Sehingga dari hasil analisis data diperoleh hasil sebagai berikut:

Tabel 14.2 Uji Parsial

\begin{tabular}{|c|c|c|c|c|c|c|}
\hline \multicolumn{7}{|c|}{ Coefficients $^{a}$} \\
\hline \multirow{2}{*}{\multicolumn{2}{|c|}{ Model }} & \multicolumn{2}{|c|}{ Unstandardized Coefficients } & \multirow{2}{*}{$\begin{array}{c}\begin{array}{c}\text { Standardized } \\
\text { Coefficients }\end{array} \\
\text { Beta } \\
\end{array}$} & \multirow[t]{2}{*}{$\mathrm{t}$} & \multirow[t]{2}{*}{ Sig. } \\
\hline & & $B$ & Std. Error & & & \\
\hline \multirow[t]{3}{*}{1} & (Constant & 9.688 & 1.223 & & 7.919 & .000 \\
\hline & PDDK & .381 & .295 & .076 & 1.293 & .197 \\
\hline & $\mathrm{BDY} \mathrm{H}$ & .343 & .057 & .352 & 5.972 & .000 \\
\hline
\end{tabular}

1. Tingkat Pendidikan

Berdasarkan tabel di atas dapat diketahui bahwa nilai sig dari tingkat pendidikan sebesar 0,197>0,05 yang berarti bahwa $\mathrm{H}_{0}$ diterima dan menolak $\mathrm{H}_{\mathrm{a}}$. Sehingga dapat disimpulkan bahwa tidak terdapat pengaruh antara variabel Tingkat Pendidikan $\left(\mathrm{X}_{1}\right)$ terhadap variabel Kepatuhan Hukum (Y).

2. Budaya Hukum

Berdasarkan tabel 4.10 dapat diketahui bahwa nilai sig dari budaya hukum sebesar $0,000<0,05$ yang berarti bahwa $\mathrm{H}_{0}$ ditolak dan menerima $\mathrm{H}_{\mathrm{a}}$. Sehingga dapat disimpulkan bahwa terdapat pengaruh antara variabel Budaya Hukum $\left(\mathrm{X}_{2}\right)$ terhadap variabel Kepatuhan Hukum (Y).

\section{Persamaan Regresi Berganda}

Berdasarkan hasil analisis yang telah dilakukan dengan bantuan software SPSS diperoleh persamaan regresi berganda sebagai berikut:

$$
Y=9,688+0,381 X_{1}+0,343 X_{2}+e
$$

Dari persamaan regresi berganda tersebut diperoleh konstanta positif yang menunjukkan pengaruh yang searah, nilai konstanta sebesar 9,688 yang berarti jika tingkat pendidikan $\left(\mathrm{X}_{1}\right)$ dan budaya hukum $\left(\mathrm{X}_{2}\right)$ diasumsi $=0$ maka kepatuhan hukum (Y) warga Kota Jambi secara konstan sebesar 9,688. Koefisien regresi variabel tingkat pendidikan $\left(\mathrm{X}_{1}\right)$ sebesar 0,381 dan bernilai positif dapat diartikan jika tingkat pendidikan mengalami peningkatan sebesar 1 satuan maka akan terjadi peningkatan pada kepatuhan hukum (Y) sebesar 0,381. Koefisien regresi variabel budaya hukum $\left(\mathrm{X}_{2}\right)$ sebesar 0,343 dan bernilai positif dapat diartikan jika budaya hukum mengalami peningkatan sebesar 1 satuan maka akan terjadi peningkatan pada kepatuhan hukum (Y) sebesar 0,343.

\section{Pengaruh Tingkat Pendidikan Terhadap Kepatuhan Hukum}

Pada penelitian ini akan menjelaskan tentang pengaruh tingkat pendidikan dan budaya hukum terhadap kepatuhan warga Kota Jambi dalam menerapkan protokol kesehatan covid-19. Berdasarkan hasil pengujian menunjukkan variabel tingkat pendidikan $\left(\mathrm{X}_{1}\right)$ memiliki sig $0,197>0,05(\alpha=5 \%)$, yang kesimpulannya $\mathrm{H}_{0}$ diterima dan menolak $\mathrm{H}_{\mathrm{a}}$. Hal tersebut memberikan arti bahwa tingkat pendidikan warga Kota Jambi secara signifikan tidak memberikan pengaruh 
terhadap kepatuhan hukum warga Kota Jambi, hal ini dikarenakan tingkat pendidikan hanya merupakan tahapan pendidikan yang ditempuh oleh individu tanpa mempengaruhi kepatuhan individu tersebut.

Hasil uji hipotesis dalam penelitian ini sesuai dengan penelitian yang dilakukan oleh Dhian, dkk (2021) yang menunjukkan bahwa tidak terdapat pengaruh tingkat pendidikan dengan kepatuhan protokol kesehatan covid-19 pada pedagang Pasar Pagi Kota Medan. Berdasarkan penelitian yang dilakukan bahwa tingkat pendidikan tidak berpengaruh terhadap kepatuhan protokol kesehatan, banyak dari responden yang memiliki pendidikan yang tinggi tidak mematuhi protokol kesehatan dengan beralasan bahwa tidak ada keluhan gejala covid-19 yang dialami.

\section{Pengaruh Budaya Hukum Terhadap Kepatuhan Hukum}

Berdasarkan hasil penelitian dan analisis data yang dilakukan dengan teknik regresi ganda menunjukkan bahwa variabel budaya hukum $\left(\mathrm{X}_{2}\right)$ memiliki nilai sig $0,000<0,05(\alpha=5 \%)$ yang kesimpulannya $\mathrm{H}_{0}$ ditolak dan menerima $\mathrm{H}_{\mathrm{a}}$. Hal tersebut berarti budaya hukum warga Kota Jambi secara signifikan memberikan pengaruh terhadap kepatuhan hukum warga Kota Jambi dalam menerapkan protokol kesehatan covid-19. Koefisien budaya hukum menunjukkan nilai positif yang artinya jika budaya hukum warga Kota Jambi semakin baik maka akan berdampak terhadap kepatuhan hukum dalam menerapkan protokol kesehatan yang semakin tinggi.

\section{Pengaruh Tingkat Pendidikan dan Budaya Hukum Terhadap Kepatuhan Hukum}

Berdasarkan pengujian dan analisis data yang dilakukan, menunjukkan bahwa secara simultan tingkat pendidikan dan budaya hukum memiliki sig 0,000 $<0,05(\alpha=5 \%)$ yang kesimpulannya menerima $\mathrm{H}_{\mathrm{a}}$ yang berarti secara signifikan variabel Tingkat Pendidikan $\left(\mathrm{X}_{1}\right)$ dan Budaya Hukum $\left(\mathrm{X}_{2}\right)$ berpengaruh secara bersama-sama terhadap variabel Kepatuhan Hukum (Y). Kemampuan variabel tingkat pendidikan dan budaya hukum dalam menjelaskan variabel kepatuhan hukum adalah sebesar 0,147 atau 14,7\%. Nilai koefisien detrminasi yang belum mencapai nilai 1 atau $100 \%$ berarti bahwa masih terdapat sebab lain atau faktorfaktor lain yang mempengaruhi kepatuhan hukum yang tidak diteliti dalam penelitian ini sebesar $85,3 \%$.

Hal ini bermakna masih sangat banyak terdapat faktor yang mempengaruhi kepatuhan hukum masyarakat dalam menerapkan protokol kesehatan, salah satunya seperti yang telah peneliti uraikan pada pembahasan sebelumnya yaitu persepsi dari masyarakat kemudian faktor usia dari masyarakat. Selain itu terdapat faktor kecemasan, sesuai dengan penelitian yang dilakukan oleh Sari dan Utami (2020) yang menghasilkan kesimpulan jika seseorang semakin cemas dengan kesehatannya maka kepatuhan untuk melaksanakan protokol kesehatan semakin meningkat begitu pula sebaliknya. Kemudian jenis kelamin dan sikap juga dapat mempengaruhi kepatuhan protokol kesehatan sesuai dengan hasil penelitian yang dilakukan oleh Wiranti, dkk (2020). Sehingga faktorfaktor tersebutlah yang menyebabkan pengaruh yang ditimbulkan oleh variabel 
tingkat pendidikan dan budaya hukum terhadap kepatuhan hukum sangat kecil. Juga disebabkan karena salah satu variabel independen yaitu tingkat pendidikan tidak berpengaruh secara parsial terhadap kepatuhan hukum sehingga menyebabkan pengaruh yang ditimbulkan semakin kecil.

\section{Simpulan}

Berdasarkan hasil analisis data dan pembahasan yang telah dilakukan dapat disimpulkan bahwa variabel tingkat pendidikan $\left(\mathrm{X}_{1}\right)$ tidak berpengaruh secara signifikan terhadap kepatuhan hukum (Y) warga Kota Jambi dalam menerapkan protokol kesehatan covid-19. Kemudian variabel budaya hukum $\left(\mathrm{X}_{2}\right)$ berpengaruh secara signifikan terhadap kepatuhan hukum (Y) warga Kota Jambi dalam menerapkan protokol kesehatan covid-19. Walaupun variabel tingkat pendidikan secara parsial tidak berpengaruh tetapi secara simultan variabel tingkat pendidikan $\left(\mathrm{X}_{1}\right)$ dan budaya hukum $\left(\mathrm{X}_{2}\right)$ mempengaruhi variabel kepatuhan hukum (Y) warga Kota Jambi dalam menerapkan protokol kesehatan covid-19, yang artinya bahwa Ha diterima dan memiliki pengaruh yang positif. Pengaruh yang positif tersebut mengartikan bahwa semakin tinggi tingkat pendidikan dan semakin baik budaya hukum masyarakat maka akan semakin tinggi pula kepatuhan hukum warga Kota Jambi dalam menerapkan protokol kesehatan covid-19.

\section{Referensi}

Agustina, Kadek Ayu. (2016). Pengaruh Tingkat Pendidikan, Tingkat Penghasilan, Dan Tarif Pajak Terhadap Kepatuhan Wajib Pajak Umkm Dalam Memenuhi Kewajiban Perpajakan Studi Empiris Pelaku UMKM di Kabupaten Buleleng. Jurnal Akuntansi Profesi, 6(1), 1-11.

Arianto, Dwi Agung Nugroho dan Samsul Arifin. 2016. Pengaruh Usia, Pendidikan dan Budaya terhadap Kepatuhan Lalu Lintas di Wilayah Hukum Polres Jepara.

Darmika, Ika. 2016. Budaya Hukum (Legal Culture) Dan Pengaruhnya Terhadap Penegakan Hukum Di Indonesia. to-ra, 2(3), 429-436.

Ginting, Tarianna, Dhian Ladea dan Raphael Ginting. 2021. Kepatuhan Pedagang Pasar Pagi dalam Melaksanakan Protokol Kesehatan Pencegahan Covid19. Prima Medika Sains, 03(1), 6-12.

Kakunsi, Erica, Sifrid Pangembanan dan Winston Pontoh. 2017. Pengaruh Gender dan Tingkat Pendidikan terhadap Kepatuhan Wajib Pajak di Wilayah Kantor Pelayanan Pajak Pratama Tahuna. Going concern Jurnal Riset Akuntansi, 12(2), 391-400.

Muhtarom, M. 2015. Pengaruh Budaya Hukum Terhadap Kepatuhan Hukum Dalam Masyarakat. Suhuf, 27(2), 121-144.

Mustopa, Ahmad, Budiman, dan Dedi Supriadi. 2020. Faktor-Faktor yang Mempengaruhi Perilaku Masyarakat dengan Kepatuhan Protokol Kesehatan 3M Sebagai Upaya Pencegahan Penyakit Covid-19. STIKES Jend. Achmad Yani Cimahi, 2(1), 116-123.

Parwata, Anak Agung Gede Oka, dkk. 2016. Buku Ajar Memahami Hukum Dan Kebudayaan. Bali: Pustaka Ekspresi. 
CIVICS EDUCATION AND SOCIAL SCIENSE JOURNAL (CESSJ)

Volume 3 Nomor 2 Edisi Bulan Desember 2021

Prakoso, Abintoro. 2017. Sosiologi Hukum. Yogyakarta: Laksbang Presindo.

Pujirahayu, Esmi Warassih, Derita Prapti Rahayu, dan Faisal. 2020. Sosiologi Hukum: Suatu Pengantar Dimensi Hukum dan Masyarakat. Yogyakarta: Litera.

Sari, Ratna Kartika. 2021. Identifikasi Penyebab Ketidakpatuhan Warga Terhadap Penerapan Protokol Kesehatan 3M di Masa Pandemi Covid-19. Jurnal Akrab Juara: Yayasan Akrab Pekanbaru, 6(1), 84-94.

Sari, Reni Puspita dan Uji Utami. 2020. Hubungan Kecemasan dan Kepatuhan dalam Pelaksanaan Protokol Kesehatan di Posyandu Malangjiwan Colomadu. STETHOSCOPE, 1(2), 114-122.

Wiranti, Ayun Sriatmi dan Wulan Kusumastuti. 2020. Determinan Kepatuhan Masyarakat Kota Depok Terhadap Kebijakan Pembatasan Sosial Berskala Besar dalam Pencegahan Covid-19. Jurnal Kebijakan Kesehatan Indonesia, 9(03), 117-124 